\title{
MAPT wt Allele
}

National Cancer Institute

\section{Source}

National Cancer Institute. MAPT wt Allele. NCI Thesaurus. Code C75636.

Human MAPT wild-type allele is located in the vicinity of $17 q 21.1$ and is approximately $134 \mathrm{~kb}$ in length. This allele, which encodes microtubule-associated protein tau, may play a role in the development and maintenance of neuronal polarity. Mutations in the gene are associated with a large number of neurodegenerative diseases. 